\title{
Synthesis of $2^{\prime}$-paclitaxel methyl 2-glucopyranosyl succinate for specific targeted delivery to cancer cells
}

\author{
Der-Zen Liu, ${ }^{\mathrm{a}}$ Supachok Sinchaikul, ${ }^{\mathrm{b}, \mathrm{c}}$ Peddiahgari Vasu Govardhana Reddy, \\ Meng-Yang Chang ${ }^{\mathrm{d}}$ and Shui-Tein Chen ${ }^{\mathrm{b}, \mathrm{e}, *}$ \\ ${ }^{a}$ Graduate Institute of Biomedical Materials, Taipei Medical University, Taipei 110, Taiwan \\ ${ }^{\mathrm{b}}$ Institute of Biological Chemistry and Genomics Research Center, Academia Sinica, Taipei 11529, Taiwan \\ ${ }^{\mathrm{c}}$ ALPS Biotech Co. Ltd, Taipei 11529, Taiwan \\ ${ }^{\mathrm{d}}$ Department of Applied Chemistry, National University of Kaohsiung, Kaohsiung 811, Taiwan \\ ${ }^{\mathrm{e}}$ Institute of Biochemical Sciences, College of Life Science, National Taiwan University, Taipei 10617, Taiwan
}

Received 9 August 2006; revised 1 November 2006; accepted 2 November 2006

Available online 7 November 2006

\begin{abstract}
A novel glucose-conjugated paclitaxel 5 was synthesized using succinic acid as linker between $2^{\prime}$-paclitaxel and methyl 2'glucopyranose. 5 has not only improved the pharmaceutical properties of paclitaxel, such as solubility and stability, but also enhanced the specific target delivery to MCF-7 cells without the cytotoxicity against normal cells. Therefore, the glucose conjugation may be potentially used in the targeted delivery of other drugs into cells via glucose transporters (GLUTs) for cancer therapy. (C) 2006 Elsevier Ltd. All rights reserved.
\end{abstract}

Glucose is an important energy source for living organisms. There are three routes of glucose uptake in human. First, glucose diffuses slowly through the cell membrane of the human tissues by passive transport. Second, glucose is absorbed into the intestinal and kidney epithelial cells by utilizing specific sodium-glucose transporters, such as SGLT-1 and SGLT-2. ${ }^{1}$ Third, glucose is transported across the human cells by the facilitative glucose transporters (GLUTs) on cell membrane, by which this route is the main glucose uptake across the cell membrane. $^{2-4}$ In general, cancer cells express higher levels of GLUTs than do normal cells and these transporters belong to a family of homologous proteins (GLUT-17) that differ in their tissue distribution and affinity for glucose. Accordingly, the purpose of this present investigation is to design a novel vehicle that improves the physiological property of potent drug and facilitates the delivery of drugs to specific carcinoma cells via the GLUTs.

Paclitaxel is a potent anticancer drug used for the treatment of breast, ovarian, and lung carcinomas. ${ }^{5-8}$ In spite of its potent anticancer activity, the poor water solubil-

\footnotetext{
Keywords: Paclitaxel; Glucose; Targeted delivery; Cancer cells.

* Corresponding author. Tel.: +886 22788 6230; fax: +886 22785

5981; e-mail: bcchen@gate.sinica.edu.tw
}

ity of paclitaxel seriously reduces its wider clinical application. There is considerable difficulty in developing paclitaxel to be widely used due to the hydrophobic molecule with low aqueous solubility. Although many attempts have been employed to improve the solubility and pharmacological properties of paclitaxel, such as cosolvent systems, emulsification, micellization, liposome formation, nanoparticle conjugate, and inclusion in cyclodextrins, ${ }^{9-12}$ none of these paclitaxel derivatives or prodrugs have been applied to use in the clinical test. Among the most notable paclitaxel derivatives synthesized so far are those in which the C-2' and C- $7^{\prime}$ hydroxyl groups of the molecule are engaged in a functional group that collapses, upon in vivo activation, releasing paclitaxel. ${ }^{13-16}$ Thus, the design and chemical synthesis of novel derivatives of paclitaxel, in which the C-2' hydroxyl group is functionalized, is interested in pursuing a program that synthesized glucose-conjugated paclitaxel 5 as a novel prodrug (Scheme 1) for enhancing the solubility and specific targeted delivery of paclitaxel to the cancer cells via GLUTs.

The synthesis of $\mathbf{5}$ was carried out according to Scheme 2 . Briefly, $2^{\prime}$-succinyl paclitaxel $\mathbf{2}$ was prepared by conjugation of paclitaxel 1 with succinic anhydride in the presence of DIPEA and dry dichloromethane. ${ }^{16,17} \mathbf{2}$ was reacted with 3-O-benzyl-4,6- $O$-benzylidene methyl$\alpha$-D-glucopyranoside 3 in the presence of DCC and 


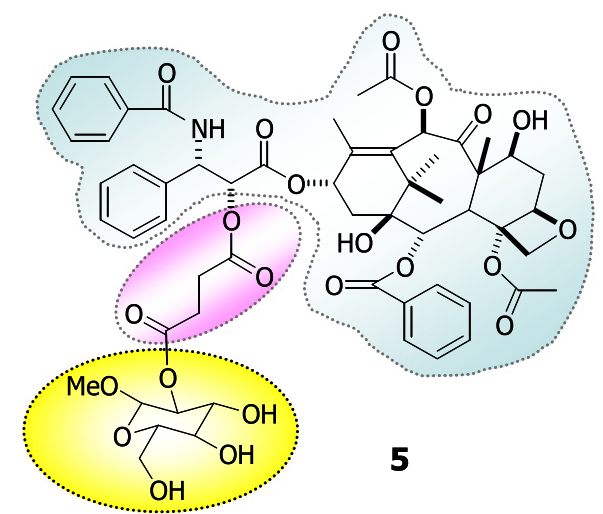

Scheme 1. Structure of novel glucose-conjugated paclitaxel 5.

DMAP in dry THF to get the compound $4 .{ }^{18,19}$ Compound 4 was hydrogenated with the excess of $10 \% \mathrm{Pd} /$ $\mathrm{C}$ in ethanol to obtain $\mathbf{5 .}^{20,21}$ The structure of synthesized derivatives was determined by ${ }^{1} \mathrm{H}$ NMR and ${ }^{13} \mathrm{C}$ NMR, and the molecular mass was determined by mass spectrometer. In order to examine the effect of succinic acid as linker on cell toxicity, we have examined the inhibition of 2 -succinyl paclitaxel 2 on MCF-7 cells and the results showed concentration-dependent inhibition of MCF-7 cells with the $50 \%$ inhibition at $25 \mathrm{ng} /$ $\mathrm{mL}$. Although the modification on $2^{\prime}$-hydroxyl group of paclitaxel with succinic acid appeared to reduce the toxicity of paclitaxel on MCF-7 cell growth, this linker maintained the activity of paclitaxel upon the concentration used and could be used for the next conjugation with 2 '-glucopyranose.

The solubility of $\mathbf{5}$ in water was determined to be $0.35 \mathrm{mg} / \mathrm{mL}$ which was 88 -fold increased as compared with paclitaxel that showed the solubility in water to be $<0.004 \mathrm{mg} / \mathrm{mL}$ and required the formulation of emulsions between alcohol and oils, such as Cremophor EL. ${ }^{22,23}$ The $2^{\prime}$-glucose conjugation of $\mathbf{5}$ could decrease the lipophilicity of the drug and allowed to formulate in aqueous solution. In addition, the stability of 5 in human serum $(4 \mu \mathrm{g} / \mathrm{mL}$ serum $)$ at $37^{\circ} \mathrm{C}$ was examined in vitro by incubating $\mathbf{5}$ in human serum, extracting $\mathbf{5}$ with dichloromethane, and analyzing by RP-HPLC using C18 column. ${ }^{24}$ Compound 5 was stable in the human serum for $4 \mathrm{~h}$ with the stability up to $85 \%$ and slowly decreased until $96 \mathrm{~h}$. The half-life of $\mathbf{5}$ in human serum was approximately $66 \mathrm{~h}$, which was longer than that of paclitaxel. ${ }^{25}$ Thus, the glucose conjugate could enhance both the solubility and the stability of 5 that may be useful for preclinical test. Moreover, the glucose conjugate in 5 was not hydrolyzed along experimental time, by which its molecular weight was confirmed by mass spectrometry. It indicated that the succinic acid serving as linker was the strong linkage between glucose and $\mathbf{5}$.

The inhibitory activity of $\mathbf{5}$ against eight cancer cells appeared to be less active than paclitaxel, except that

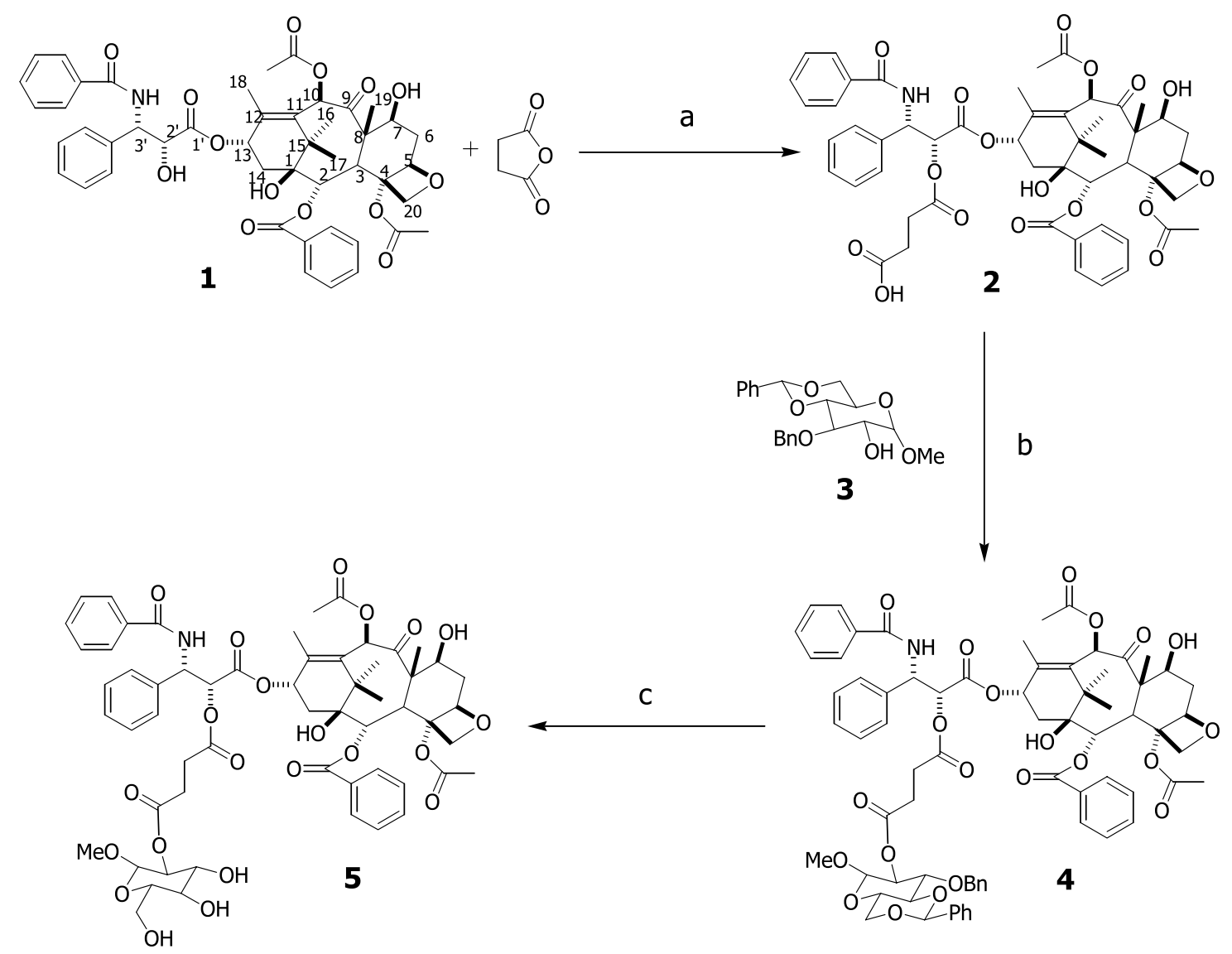

Scheme 2. Synthesis of glucose-conjugated paclitaxel 5. Reagents and conditions: (a) DIPEA/DCM, rt, 4 h, $98 \%$; (b) THF, DMAP, DCC, $0{ }^{\circ} \mathrm{C}, 24 \mathrm{~h}$, $27 \%$; (c) $\mathrm{Pd} / \mathrm{C}, \mathrm{H}_{2}$, EtOH, rt, 4 h, $88 \%$. 
MCF-7 cells showed the similar IC $_{50}$ values (Table 1 ). It was evident that $\mathbf{5}$ showed a great specific inhibition with MCF-7 cells, while the other cells appeared to be less active as opposite to paclitaxel. The cell morphology of MCF-7 cells treated with $\mathbf{5}$ at $\mathrm{IC}_{50}$ of $0.0007 \mu \mathrm{M}$ was also distinctly changed and the total cell number was less than half that of control (Fig. 1). On the other hand, 5 had not affected the RPTEC normal cells, whereas paclitaxel strongly inhibited its cell proliferation. The selectivity index (SI) was determined by the proportion of the $\mathrm{IC}_{50}$ of cancer cells against that of RPTEC normal cells and the SI values of 5 against MCF-7 and NPCTW01 cells were relatively low $(0.0004$ and 0.0046 , respectively) as compared to that of paclitaxel $(0.56$ and 0.33 , respectively). Due to no toxicity of $\mathbf{5}$ on RPTEC cells, it indicated that the conjugation of glucose could reduce the toxicity of paclitaxel and showed the safety on human epithelial cells. It also enhanced the selectivity of glucose uptake and cytotoxicity for cancer cells. In addition, the glucose uptake via GLUT in various cancer cells has been investigated using $\left[{ }^{18} \mathrm{~F}\right]$ fluorodeoxyglucose and the uptake of $\left[{ }^{18} \mathrm{~F}\right]$ glucose analogs was detected by positron-emission tomography (PET). ${ }^{36,37}$ According to cytotoxicity of $\mathbf{5}$ against various cells, it can also support our ideal that glucose could mediate drugs into cancer cells. Moreover, we have examined the fluorescein-labeled octreotide-conjugated paclitaxel in
MCF-7 cells under fluorescence microscopy. It indicated that the size of $\mathbf{5}$ was not too big to be transported by GLUTs. ${ }^{38}$ Therefore, we suggest that the glucose conjugate in $\mathbf{5}$ may be involved in the glucose uptake or glucose transport via GLUTs and leads to easy delivery of the paclitaxel to cytosol through the cell membranes for selective cancer therapy without toxicity on normal cells. Furthermore, we will study the mechanism of drug delivery by glucose transportation via GLUTs and the pharmacokinetics of $\mathbf{5}$ through the therapeutic application.

In summary, we successfully developed the drug delivery based on the glucose transportation via GLUTs on cell membranes. The novel prodrug 5 showed the improved pharmaceutical properties and the excellent selective cytotoxicity against MCF-7 breast cancer cells without toxicity on normal cells. Furthermore, 5 may be potentially used for therapeutic application of breast cancer and the drug design based on glucose conjugate may be useful for targeted delivery of other drugs.

\section{Supplementary data}

Supplementary data associated with this article can be found, in the online version, at doi:10.1016/j.bmcl. 2006.11.008.

Table 1. Comparison of cytotoxicity between paclitaxel and $\mathbf{5}$ against various cells

\begin{tabular}{|c|c|c|c|c|}
\hline \multirow[t]{2}{*}{ Cells } & \multirow[t]{2}{*}{ Cell type } & \multirow[t]{2}{*}{ GLUTs } & \multicolumn{2}{|c|}{$\mathrm{IC}_{50}{ }^{\mathrm{a}}(\mu \mathrm{M})$} \\
\hline & & & Paclitaxel & 5 \\
\hline 1. A498 & Renal carcinoma & GLUT-1 ${ }^{26}$ & 0.0610 & 0.2577 \\
\hline 2. NPC-TW01 & Nasopharyngeal carcinoma & GLUT-1 $1^{\mathrm{b}, 27}$ & 0.0003 & 0.0072 \\
\hline 3. НCТ-116 & Colon carcinoma & GLUT- $1^{28}$ & 0.0006 & 0.0256 \\
\hline 4. $\mathrm{MCF}-7$ & Breast adenocarcinoma & GLUT $-1^{29},-2^{29},-3^{29},-5^{29},-12^{30}$ & 0.0005 & 0.0007 \\
\hline 5. Нер3B & Heptocellular carcinoma & GLUT-1 ${ }^{31}$ & 0.0054 & 0.0603 \\
\hline 6. MKN45 & Gastric carcinoma & GLUT $-1^{32},-4^{32}$ & 0.0005 & 0.0141 \\
\hline 7. MES-SA & Uterine sarcoma & GLUT $-1^{\mathrm{b}, 33}$ & 0.0005 & 0.0091 \\
\hline 8. NCI-H226 & Non-small cell lung cancer (squamous carcinoma) & GLUT-1 ${ }^{\text {b,34 }}$ & 0.0068 & 0.1140 \\
\hline 9. RPTEC & Renal tubular epithelial cells & GLUT-1 ${ }^{35}$ & 0.0009 & 1.5750 \\
\hline
\end{tabular}

${ }^{a}$ Eight cancer cells (A498, NPC-TW01, HCT-116, MCF-7, Hep3B, MKN45, MES-SA, NCI-H226) and one normal cells (RPTEC) were examined.

The values of $\mathrm{IC}_{50}(50 \%$ inhibition concentration) represent the means of at least three independent experiments with SD less than $10 \%$.

${ }^{\mathrm{b}}$ Expected GLUT, according to references of GLUT in cancer cells.
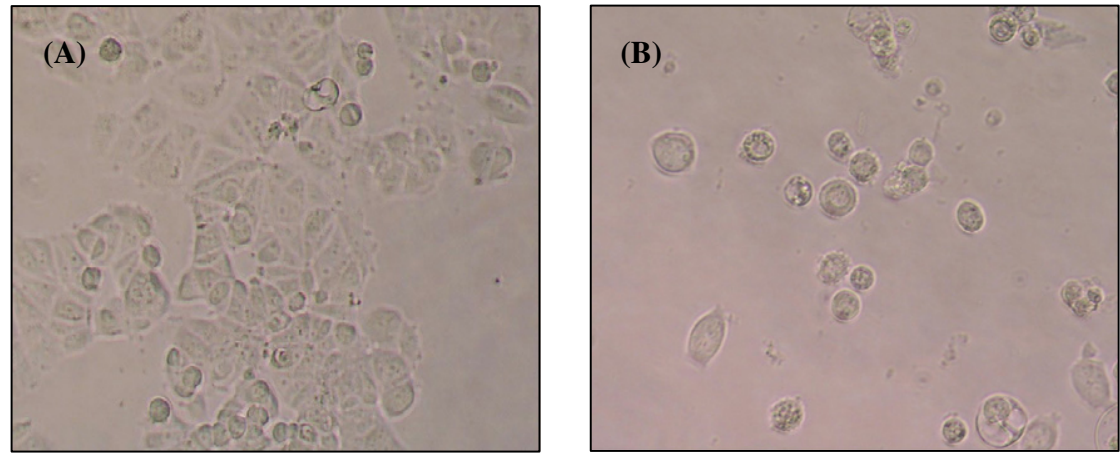

Figure 1. Cell morphological changes of MCF-7 cells (A) and MCF-7 cells treated with $5(0.0007 \mu \mathrm{M})(\mathrm{B})$ for $72 \mathrm{~h}$. 


\section{References and notes}

1. Kanai, Y.; Lee, W. S.; You, G.; Brown, D.; Hediger, M. A. J. Clin. Invest. 2004, 93, 397.

2. Longo, N.; Elsas, L. J. Adv. Pediatr. 1998, 45, 293.

3. Kayano, T.; Burant, C. F.; Fukumoto, H.; Gould, G. W.; Fan, Y. S.; Eddy, R. L.; Byers, M. G.; Shows, T. B.; Seino, S.; Bell, G. I. J. Biol. Chem. 1990, 265, 13276.

4. Wheeler, T. J.; Hinkle, P. C. Annu. Rev. Physiol. 1985, 47, 503.

5. Rowinsky, E. K.; Donehower, R. C. N. Engl. J. Med. 1995, 332, 1004.

6. Passardi, A.; Massa, I.; Zoli, W.; Gianni, L.; Milandri, C.; Zumaglini, F.; Nanni, O.; Maltoni, R.; Frassineti, G. L.; Amadori, D. BMC Cancer 2006, 6, 76.

7. Eisenhauer, E. A.; ten Bokkel Huinink, W. W.; Swenerton, K. D.; Gianni, L.; Myles, J.; van der Burg, M. E.; Kerr, I.; Vermorken, J. B.; Buser, K.; Colombo, N. J. Clin. Oncol. 1994, 12, 2654.

8. Akerley, W.; Herndon, J. E.; Egorin, M. J.; Lyss, A. P.; Kindler, H. L.; Savarese, D. M.; Sherman, C. A.; Rosen, D. M.; Hollis, D.; Ratain, M. J.; Green, M. R. Cancer 2003, 97, 2480.

9. Lee, J.; Lee, S. C.; Acharya, G.; Chang, C. J.; Park, K. Pharm. Res. 2003, 20, 1022.

10. Dhanikula, A. B.; Panchagnula, R. Curr. Drug Deliv. 2005, 2, 75 .

11. Schmitt-Sody, M.; Strieth, S.; Krasnici, S.; Sauer, B.; Schulze, B.; Teifel, M.; Michaelis, U.; Naujoks, K.; Dellian, M. Clin. Cancer Res. 2003, 9, 2335.

12. Liu, Y.; Chen, G. S.; Chen, Y.; Cao, D. X.; Ge, Z. Q.; Yuan, Y. J. Bioorg. Med. Chem. 2004, 12, 5767.

13. Rodrigues, M. L.; Carter, P.; Wirth, C.; Mullins, S.; Lee, A.; Blackburn, B. K. Chem. Biol. 1995, 2, 223.

14. Golik, J.; Wong, H. S. L.; Chen, S. H.; Doyle, T. W.; Wright, J. J. K.; Knipe, J.; Rose, W. C.; Casazza, A. M.; Vyas, D. M. Bioorg. Med. Chem. Lett. 1996, 6, 1837.

15. Lee, J. W.; Fuchs, P. L. Org. Lett. 1999, 1, 179.

16. Kirschberg, T. A.; VanDeusen, C. L.; Rothbard, J. B.; Yang, M.; Wender, P. A. Org. Lett. 2003, 5, 3459.

17. Kleinert, M.; Rockendorf, N.; Lindhorst, T. K. Eur. J. Org. Chem. 2004, 18, 3931.

18. Tinazli, A.; Tang, J.; Valiokas, R.; Picuric, S.; Lata, S.; Piehler, J.; Liedberg, B.; Tampe, R. Chemistry 2005, 11, 5249.
19. Hunt, D. K.; Seeberger, P. H. Org. Lett. 2002, 16, 2751.

20. Dorn, I. T.; Neumaier, K. R.; Tampe, R. J. Am. Chem. Soc. 1998, 120, 2753.

21. Lindberg, J.; Ekeroth, J.; Konradsson, P. J. Org. Chem. 2002, 67, 194.

22. Gelderblom, H.; Verweij, J.; Nooter, K.; Sparreboom, A. Eur. J. Cancer 2001, 37, 1590.

23. Wrasidlo, W.; Gaedicke, G.; Guy, R. K.; Renaud, J.; Pitsinos, E.; Nicolaou, K. C.; Reisfeld, R. A.; Lode, H. N. Bioconjugate Chem. 2002, 13, 1093.

24. Coudoré, F.; Authier, N.; Guillaume, D.; Béal, A.; Duroux, E.; Fialip, J. J. Chromatogr., B 1999, 721, 317.

25. Rowinsky, E. K.; Cazenave, L. A.; Donehower, R. C. J. Natl. Cancer Inst. 1990, 82, 1247.

26. Raval, R. R.; Lau, K. W.; Tran, M. G. B.; Sowter, H. M.; Mandriota, S. J.; Li, J. L.; Pugh, C. W.; Maxwell, P. H.; Harris, A. L.; Ratcliffe, P. J. Mol. Cell. Biol. 2005, 25, 5675.

27. Isa, A. Y.; Phil, M.; Ward, T. H.; West, C. M. L.; Slevin, N. J.; Homer, J. J. Br. J. Radiol. 2006, 79, 791.

28. Funasaka, T.; Yanagawa, T.; Hogan, V.; Raz, A. FASEB J. 2005, 19, 1422.

29. Grover-Mckay, M.; Walsh, S. A.; Seftor, E. A.; Thomas, P. A.; Hendrix, M. J. C. Pathol. Oncol. Res. 1998, 4, 115.

30. Rogers, S.; Macheda, M. L.; Docherty, S. E.; Carty, M. D.; Henderson, M. A.; Soeller, W. C.; Gibbs, E. M.; James, D. E.; Best, J. D. Am. J. Physiol. Endocrinol. Metab. 2002, 282, E733.

31. Gleadle, J. M.; Ratcliffe, P. J. Blood 1997, 89, 503.

32. Noguchi, Y.; Sato, S.; Marat, D.; Doi, C.; Yoshikawa, T.; Saito, A.; Ito, T.; Tsuburaya, A.; Yanuma, S. Cancer Lett. 1999, 140, 69.

33. Pandit-Taskar, N. J. Nucl. Med. 2005, 46, 1842.

34. Ito, T.; Noguchi, Y.; Satoh, S.; Hayashi, H.; Inayama, Y.; Kitamura, H. Mod. Pathol. 1998, 11, 437.

35. Jiang, Y.; Zhang, W.; Kondo, K.; Klco, J. M.; St Martin, T. B.; Dufault, M. R.; Madden, S. L.; Kaelin, W. G.; Nacht, M. Mol. Cancer Res. 2003, 1, 453.

36. Ilknur, A. K.; Stokkel, M. P. M.; Pauwels, E. K. J. J. Cancer Res. Clin. Oncol. 2000, 126, 560.

37. Pauwels, E. K. J.; Sturm, E. J. C.; Bombardieri, E.; Cleton, F. J.; Stokkel, M. P. M. J. Cancer Res. Clin. Oncol. 2000, 126, 549.

38. Huang, C. M.; Wu, Y. T.; Chen, S. T. Chem. Biol. 2000, 7, 453. 